DOI: $10.31933 / \mathrm{JIMT}$

Received: 10 Agustus 2020, Revised: 25 Agustus 2020, Publish: 22 September 2020

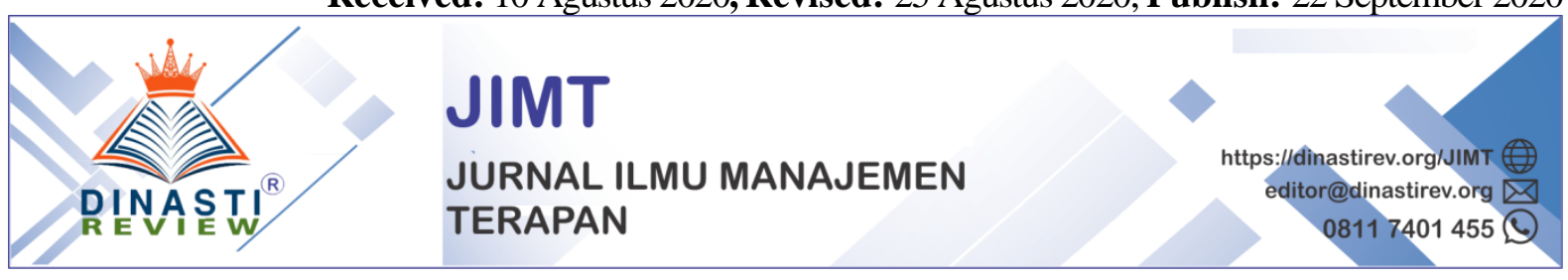

\title{
MENGUKUR MINAT BELI KONSUMEN MELALUI KEPUASAN KONSUMEN PADA PT. MENARA AGUNG PADANG
}

\author{
Mondra Neldi ${ }^{1}$, Vicky Brama Kumbara ${ }^{2}$, Yunita ${ }^{3}$ \\ 1) Universitas Putra Indonesia YPTK Padang, Indonesia, mondraneldi@gmail.com \\ 2) Universitas Putra Indonesia YPTK Padang, Indonesia, vickybrama@upiyptk.ac.id \\ 3) Universitas Putra Indonesia YPTK Padang, Indonesia, itayunita1967@gmail.com
}

\section{Corresponding Author: First Author}

Abstrak: Tujuan dari penelitian ini adalah untuk mengetahui seberapa besar Pengaruh Kualitas Produk dan Promosi Terhadap Kepuasan Konsumen dan seberapa besar Pengaruh Kualitas Produk, Promosi dan Kepuasan Konsumen Terhadap Minat Beli pada PT. Menara Agung. Teknik pengumpulan data menggunakan kuesioner, jumlah sampel pada penelitian ini yaitu 100 responden, jenis penelitian kuantitatif. yang digunakan adalah analisis jalur (Path Analysis) menggunakan SPSS 22. Hasil peneitian didapatkan Kualitas Produk dan Promosi secara parsial berpengaruh signifikan terhadap Kepuasan Konsumen pada PT. Menara Agung. Dan juga didapatkan Kualitas Produk, Promosi dan Kepuasan Konsumen secara parsial berpengaruh signifikan terhadap Minat Beli pada PT. Menara Agung. Kepuasan Konsumen (Z) memediasi hubungan antara Kualitas Produk (X1) terhadap Minat Beli (Y). Kepuasan Konsumen (Z) tidak memediasi hubungan antara Promosi (X2) terhadap Minat Beli (Y)

Kata Kunci : Kualitas Produk, Promosi, Minat Beli, Kepuasan Konsumen

\section{PENDAHULUAN}

Pada era persaingan yang begitu ketat saat ini, manusia dituntut untuk dapat menerapkan efisiensi dan efektifitas dalam semua aktivitasnya, begitu pula dalam hal mobilitas dari satu tempat ketempat lain. Hal ini tentu akan berpengaruh terhadap pemilihan alat transportasi yang akan digunakan. Dalam kondisi saat ini, dari semua alat transportasi yang ada, sepeda motor menjadi favorit masyarakat karena dianggap paling efektif dan efisien. Pilihan masyarakat ini tentu menjadi sebuah peluang besar bagi pelaku bisnis otomotif, terutama dibidang kendaraan bermotor roda dua, untuk terus meningkatkan penjualannya dengan penerapan strategi pemasaran yang tepat. Inovasi yang dapat memenuhi kebutuhan dan selera konsumen mutlak diperlukan jika pelaku bisnis tidak ingin kehilangan konsumennya serta menumbuhkan permintaan akan produknya.

Mempertahankan dan bahkan menumbuhkan permintaan baru tentu bukan perkara mudah bagi para pelaku bisnis. Selain itu, menurut Kotler (2015), pekerjaan pemasaran bukan bagaimana menemukan konsumen yang tepat untuk sebuah produk tapi bagaimana menemukan produk yang tepat untuk konsumen. Oleh karena itu, sangat penting bagi produsen untuk terus berinovasi dan melakukan promosi secara gencar untuk dapat mempertahankan dan menumbuhkan permintaan baru. 
Menurut Sangadji dan Sopiah (2013:123), minat beli adalah proses pemecahan masalah yang diarahkan pada sasaran. Pemecahan masalah konsumen sebenarnya merupakan suatu aliran tindakan timbal balik yang berkesinambungan diantara faktorfaktor lingkungan, proses kognitif dan efektif, serta tindakan perilaku. Faktor-faktor yang mempengaruhi minat beli menurut Kotler \& keller (2007:226), diperlihatkan pada model perilaku konsumen yaitu, minat beli dirangsang oleh stimuli marketing mix, ada produk.

Menurut Kotler (2014:150), kepuasan pelanggan adalah perasaan senang atau kecewa yang muncul setelah membandingkan kinerja (hasil) produk yang dipikirkan terhadap kinerja (atau hasil) yang diharapkan. Kepuasan pelanggan dapat dirasakan setelah pelanggan membandingkan pengalaman mereka dalam melakukan pembelian barang/jasa dari penjual atau penyedia barang/jasa dengan harapan dari pembeli itu sendiri, pemasar yang ingin unggul dalam persaingan tentu harus memperhatikan harapan pelanggan serta kepuasan pelanggannya.

Menurut Kotler dan Amstrong (2014:231), kualitas produk adalah the characteristics of a product of service that bear on its ability to satisfy stated or implied customer need, yang berarti kualitas produk adalah karakteristik dari produk dan jasa yang menunjang kemampuannya untuk memuaskan kebutuhan konsumen. Jadi kualitas produk adalah kemampuan suatu produk untuk melaksanakan fungsinya meliputi daya tahan keandalan, ketepatan kemudahan operasi dan perbaikan, serta atribut bernilai lainnya.

Menurut Handoko (2017), Promosi adalah komunikasi dari para pemasar yang menginformasikan, membujuk dan mengingatkan para calon pembeli suatu produk dalam rangka mempengaruhi pendapat mereka atau memperoleh suatu respon yang baik. Promosi juga merupakan kegiatan-kegiatan yang dilakukan oleh perusahaan (penjual) untuk mendorong konsumen untuk membeli produk atau jasa yang ditawarkan. Suatu produk tidak akan berguna selama produk tersebut tidak sampai ketangan konsumen yang membutuhkan dan tentunya konsumen tidak akan mengetahui akan keberadaan produk jika tanpa adanya kegiatan promosi.

Saat ini banyak sekali bermunculan merek sepeda motor dengan berbagai merek, model dan desain. Dan juga menawarkan kualitas produk yang bagus dan harga yang cukup bersaing. Hal ini ditunjukkan pada semakin maraknya showroom atau dealer sepeda motor yang tersebar seluruh kota di Indonesia termasuk di kota Padang salah satunya PT. Menara Agung.

Permintaan akan sepeda motor terus mengalami peningkatan dari tahun ke tahun. Masyarakat kota Padang banyak menggunakan sepeda motor sebagai alat penunjang mobilitasnya karena dinilai sangat efektif dan efesien. Dilihat dari fungsi sepeda motor bagi masyarakat, mereka lebih senang pada produk sepeda motor yang dikeluarkan oleh produsen terkemuka dinegri ini, karna dirasa telah memiliki kualitas terjamin. Selama ini produk dari Jepang mendapat tempat yang lebih tinggi dibandingkan dengan produk dari Cina maupun Korea.

Berbagai produsen sepeda motor yang terkenal di Indonesia salah satunya sepeda motor merek Honda yang banyak diminati oleh masyarakat khususnya di Kota Padang. PT. Menara Agung merupakan dealer resmi sepeda motor Honda di Kota Padang. Kualitas Produk yang ditawarkan merek sepeda motor Honda sudah dipercaya oleh masyarakat indonesia, PT. Menara Agung menjual berbagi jenis sepeda motor merek Honda. Dan strategi pemasaran yang dilakukan oleh PT. Menara Agung salah satunya yaitu melakukan Promosi untuk dapat menarik konsumen.

Untuk lebih jelasnya, angka penjualan dari sepeda motor merek Honda masih menjadi yang tertinggi. Tercatat selama tahun 2018-2019 sepeda motor merek Honda 
selalu mengalami peningkatan penjualannya di Indonesia. Berikut data AISI penjualan dari tahun 2018-2019 dari beberapa merek sepeda motor, di bawah ini :

Tabel 1.1 Data AISI Penjualan pada tahun 2018-2019 :

\begin{tabular}{|l|l|l|l|l|l|}
\hline & Terjual & Persentase & & Terjual & Persentase \\
\hline 1. Honda & 4.759 .202 unit & $74,6 \%$ & 1. Honda & 4.910 .688 unit & $75,69 \%$ \\
\hline 2. Yamaha & 1.455 .088 unit & $22,8 \%$ & 2. Yamaha & 1.434 .217 unit & $22,10 \%$ \\
\hline 3. Suzuki & 89.508 unit & $1,4 \%$ & 3. Suzuki & 71.861 unit & $1,10 \%$ \\
\hline $\begin{array}{l}\text { 4. } \\
\text { Kawasaki }\end{array}$ & 78.982 unit & $1,22 \%$ & $\begin{array}{l}\text { 4. } \\
\text { Kawasaki }\end{array}$ & 69.766 unit & $1,07 \%$ \\
\hline 5. TVS & 331 unit & $0,01 \%$ & 5. TVS & 898 unit & $0,01 \%$ \\
\hline Total : & $\mathbf{6 . 3 8 3 . 1 1 1}$ & $\mathbf{1 0 0 \%}$ & Total : & $\mathbf{6 . 4 8 7 . 4 3 0}$ & $\mathbf{1 0 0 \%}$ \\
\hline
\end{tabular}

Sumber : AISI (Asosiasi Sepeda Motor Indonesia)

Data yang diperoleh dari AISI pada tabel 1.1 menjelaskan adanya peningkatan dari tahun 2018-2019, dan sepeda motor merek Honda masih menjadi penguasa pangsa pasar di industri sepeda motor Indonesia, dan disusul oleh merek Yamaha dan selanjutnya Suzuki, Kawasaki dan TVS. Dan kondisi ini membuat kompetensi diantara perusahaan industri seepeda motor di Indonesia semakin ketat dan perusahaan menerapkan strategi pemasaran yang tepat untuk meningkatkan penjualan.

Dari data tersebut juga dapat dilihat bahwa konsumen lebih memilih sepeda motor merek Honda dapat dilihat dari tahun 2018-2019 dibandingkan sepeda motor merek lainnya dengan total penjualan setiap tahun meningkat dari 4.759.202 unit - 4.910.688 unit. Sedangkan posisi terendah yaitu sepeda motor merek TVS yaitu sebesar 898 unit pada tahun 2019. Sepeda motor merek Honda masih dipercaya oleh konsumen akan kualitas produknya yang terjamin dan promosi yang diterapkan merek Honda sangat dapat menarik konsumen sehingga setiap tahunnya penjualan sepeda motor merek Honda terus meningkat dan menguasai pasar sebesar 75,69\% dari industri sepeda motor Indonesia.

Ada beberapa Dealer resmi sepeda motor Honda di Kota Padang, salah satunya PT. Menara Agung. PT. Menara Agung harus dapat menerapkan strategi pemasaran yang bagus agar minat beli konsumen terus meningkat dan juga konsumen merasa puas dari semua layanan yang diberikan PT. Menara Agung selaku dealer resmi Honda. Jika strategi yang diterapkan lemah maka PT. Menara Agung akan kalah saing dengan dealer resmi Honda lainnya. Promosi sangat penting bagi setiap perusahaan, dengan berbagai macam Promosi yang diterapkan sehingga dapat menarik konsumen agar minat beli konsumen terus meningkat dan kualitas produk yang bagus dapat meningkatkan Kepuasan Konsumen.

Berdasarkan latar belakang masalah diatas, maka dapat dirumuskan masalah yang akan diteliti sebagai berikut: 
1. Bagaimanakah pengaruh kualitas produk terhadap kepuasan konsumen pada PT. Menara Agung?

2. Bagaimanakah pengaruh promosi terhadap kepuasan konsumen pada PT. Menara Agung?

3. Bagaimanakah pengaruh kualitas produk terhadap minat beli pada PT. Menara Agung?

4. Bagaimanakah pengaruh promosi terhadap minat beli pada PT. Menara Agung?

5. Bagaimanakah pengaruh kepuasan konsumen terhadap minat beli pada PT. Menara Agung?

6. Bagaimanakah pengaruh kualitas produk terhadap minat beli melalui kepuasan konsumen sebagai variabel inntervening pada PT. Menara Agung?

7. Bagaimanakah pengaruh promosi terhadap minat beli melalui kepuasan konsumen sebagai variabel intervening pada PT. Menara Agung?

\section{KAJIAN PUSTAKA}

\subsubsection{Minat Beli}

\subsubsection{Pengertian Minat Beli}

Minat beli adalah tahap kecenderungan responden untuk bertindak sebelum keputusan membeli benar-benar dilaksanakan. Terdapat perbedaan antara pembelian aktual dan minat pembelian. Bila pembelian aktual adalah pembelian yang benar-benar dilakukan oleh konsumen, maka minat pembelian adalah niat untuk melakukan pembelian pada kesempatan mendatang. Meskipun merupakan pembelian yang belum tentu akan dilakukan pada masa mendatang namun pengukuran terhadap minat pembelian umumnya dilakukan guna memaksimumkan prediksi terhadap pembelian aktual itu sendiri.

Menurut Tjiptono (2015:71), minat beli adalah proses pembelian yang dipengaruhi oleh mood. Konsumen yang sedang dalam mood positif, misalnya cenderung lebih efisien dalam pemrosesan informasi dan pembuatan keputusan, artinya mereka membuat keputusan lebih cepat. Sedangkan mereka yang sedang dalam mood negatif cenderung mempertimbangkan hal-hal rinci.

Menurut Kotler \& Keller (2007), minat beli adalah konsumen membentuk preferensi antar merek dalam kumpulan pilihan. Konsumen juga membentuk maksud untuk membeli merek yang paling disukai. Dalam melaksanakan maksud pembelian, konsumen dapat membentuk lima subkeputusan: merek (merek A), penyalur (penyalur 2), kuantitas (suatu computer), waktu (akhir minggu), dan metode pembayaran (kartu kredit).

Menurut Sangadji dan Sopiah (2013:123), minat beli adalah proses pemecahan masalah yang diarahkan pada sasaran. Pemecahan masalah konsumen sebenarnya merupakan suatu aliran tindakan timbal balik yang berkesinambungan diantara faktorfaktor lingkungan, proses kognitif dan efektif, serta tindakan perilaku.

\subsubsection{Kepuasan Pelanggan}

\subsubsection{Pengertian Kepuasan Pelanggan}

Dalam suatu bisnis pada dasarnya untuk menciptakan rasa puas terhadap pelanggan. pencapaian kepuasan dapat merupakan proses yang sederhana namun komplek. Konsep kepuasan bisa dikatakan masih bersifat abstrak, setiap pelayanan yang diberikan sangat penting dalam terciptanya kepuasan pelanggan. Menurut Kotler (2014:150) kepuasan pelanggan adalah perasaan senang atau kecewa yang muncul setelah membandingkan kinerja (hasil) produk yang dipikirkan terhadap kinerja (atau hasil) yang diharapkan. 
Menurut Umar (2015:65) kepuasan pelanggan adalah tingkat perasaan konsumen setelah membandingkan antara apa yang diterima dan harapannya. Seorang konsumen, jika merasa puas dengan nilai yang diberikan oleh produk atau jasa, sangat besar kemungkinan menjadi pelanggan dalam waktu yang lama.

Dan menurut J.Paul Peter dan Jerry C.Olson (2014:184) kepuasan konsumen adalah jika konsumen merasa puas dengan produk, jasa, atau merek, kemungkinan besar akan terus membelinya dan memberitahukan kepada yang lain perihal pengalamanpengalaman yang menyenangkan yang dirasakannya atas produk atau jasa yang digunankan.

Terciptanya kepuasan konsumen dapat memberikan beberapa manfaat diantaranya menurut Tjiptono et al, (2014:58) :

a. Hubungan perusahaan dengan kosumen menjadi harmonis

b. Memberikan dasar yang baik bagi pembeli

c. Dapat mendorong terciptanya loyalitas konsumen

d. Membentuk rekomendasi dari mulut ke mulut (word of mouth) yang mengguntungkan perusahaan.

e. Laba yang diperoleh meningkat

Dari defenisi diatas dapat ditarik kesimpulan bahwa kepuasan konsumen merupakan perbedaan antara harapan dan kinerja atau hasil yang dirasakan setelah pemakaian barang atau jasa. Umumnya harapan konsumen merupakan perkiraan atau keyakinan konsumen tentang apa yang akan diterimanya bila ia memakai jasa, sedangkan kinerja yang dirasakan setelah memakai jasa.

\subsubsection{Faktor-faktor yang mempengaruhi Kepuasan Pelanggan}

Strategi pemasaran yang diperlukan perusahaan untuk memberikan kepuasan kepada konsumen. Variabel yang mempengaruhi kepuasan konsumen menurut Priansa (2017:209) adalah :

1. Produk

Layanan produk yang baik memenuhi selera serta harapan konsumen. Produk dapat menciptakan kepuasan konsumen. Dasar penilaian terhadap pelayanan produk ini meliputi jenis produk, mutu atau kualitas produk dan persediaan produk.

2. Harga

Harga merupakan bagian yang melekat pada produk yang mencerminkan seberapa besar kualitas produk tersebut. Dasar penilaian terhadap harga meliputi tingkat harga dan kesesuaian dengan nilai jual produk, variasi atau pilihan harga terhadap produk.

3. Promosi

Dasar penelitian promosi yang mengenai informasi produk dan jasa perusahaan dalam rangka mengkomunikasikan manfaat produk dan jasa tersebut pada konsumen sasaran. Penelitian dalam hal ini meliputi iklan produk dan jasa, diskon barang dan pemberian hadiah-hadiah.

4. Lokasi

Tempat merupakan bagian dari atribut perusahaan yang berupa lokasi perusahaan dan konsumen. Penilaian terhadap atribut lokasi meliputi lokasi perusahaan, kecepatan dan ketepatan dalam transportasi.

5. Pelayanan Karyawan

Pelayanan karyawan merupakan pelayanan yang diberikan karyawan dalam usaha memenuhi kebutuhan dan keinginan konsumen dalam usaha memuaskan konsumen. 
Dasar penilitian dalam hal ini pelayanan karyawan meliputi kesopanan, keramahan, kecepatan dan ketepatan.

6. Fasilitas

Fasilitas merupakan bagian dari atribut perusahaan yang berupa perantara guna mendukung kelancaran operasional perusahaan yang berhubungan dengan konsumen. Dasar penilaian meliputi penataan barang, tempat penitipan barang, kamar kecil dan tempat ibadah.

7. Suasana

Suasana merupakan faktor pendukung, karena apabila perusahaan mengesankan maka konsumen mendapatkan kepuasan tersendiri. Dasar penilaian meliputi sirkulasi udara, kenyamanan dan keamanan.

\subsubsection{Indikator-indikator Kepuasan Pelanggan}

Indikator pembentuk kepuasan pelanggan menurut Priansa (2017:210) adalah :

1. Harapan (Expectation)

2. Kinerja (Peformance)

3. Perbandingan (Comparison)

4. Pengalaman (Experience)

5. Konfimasi (Conimation)

\subsubsection{Kualitas Produk}

\subsubsection{Pengertian Kualitas Produk}

Menurut Kotler dan Armstrong (2014:11), kualitas produk adalah kemampuan sebuah produk dalam memperagakan fungsinya, hal ini termasuk keseluruhan durabilitas, reliabilitas, ketepatan, kemudahan pengoperasian, dan reparasi produk, juga atribut produk lainnya.

Menurut Kotler dan Keller (2016:164), kualitas produk adalah kemampuan suatu barang untuk memberikan hasil atau kinerja yang sesuai bahkan melebihi dari apa yang diinginkan pelanggan. Kualitas produk memiliki suatu ketertarikan bagi konsumen dalam mengelola hubungan yang baik dengan perusahaan penyedia produk.

Menurut Kartika (2017) kualitas produk adalah mempunyai hubungan yang sangat erat dengan sikap konsumen, dimana kualitas produk memberikan suatu dorongan kepada konsumen untuk menjalin ikatan hubungan yang kuat dengan perusahaan.

Ada beberapa pendapat mengenai dimensi kualitas produk, antara lain menurut Kotler (2016:203) apabila perusahaan ingin mempertahankan keunggulan kompetitifnya dalam pasar maka perusahaan harus mengerti aspek dimensi apa saja yang digunakan oleh konsumen untuk membedakan produk yang dijual perusahaan tersebut dengan produk pesaing.

\subsubsection{Faktor-faktor kualitas produk}

Menurut Garvin (2012:121), kualitas produk memiliki faktor-faktor yang mempengaruhi kualitas produk yaitu sebagai berikut :

1. Kinerja (Performance)

merupakan karakteristik operasi dan produk inti (core product) yang dibeli. Misalnya kecepatan, kemudahan dan kenyamanan dalam penggunaan.

2. Fitur (feature)

Fitur produk yang melengkapi fungsi dasar suatu produk tersebut. 


\section{Kesesuaian dengan spesifikasi (Conformance to Spesification)}

Sejauh mana karakteristik desain dan operasi memenuhi standar yang telah ditetapkan sebelumnya. Misalnya standar karakteristik operasional.

4. Ketahanan (Durability)

Berkaitan dengan berapa lama produk tersebut dapat terus digunakan. Dimensi ini mencakup umur teknis maupun umur ekonomis.

5. Keandalan (Realibility)

Yaitu kemungkinan kecil akan mengalami kerusakan atau gagal pakai.

6. Serviceability

Meliputi kecepatan, kompetensi, kenyamanan, mudah direparasi, serta penanganan keluhan yang memuaskan. Pelayanan yang diberikan tidak terbatas hanya sebelum penjualan, tetapi juga selama proses penjualan hingga purna jual, yang juga mencakup pelayanan reparasi dan ketersediaan komponen yang dibutuhkan.

7. Estetika (Esthetica)

Yaitu daya tarik produk terhadap panca indera. Misal keindahan desain produk, keunikan model produk, dan kombinasi.

8. Kualitas yang dipersepsikan (Perceived Quality)

Merupakan persepsi konsumen terhadap keseluruhan kualitas atau keunggulan suatu produk. Biasanya karena kurangnya pengetahuan pembeli akan atribut atau ciri-ciri produk yang akan dibeli, maka pembeli mempersepsikan kualitasnya dari aspek harga, iklan, reputasi perusahaan, maupun negara pembuatnya.

\subsubsection{Indikator Kualitas Produk}

Adapun indikator kualitas produk menurut Tjiptono (2015) adalah sebagai berikut :

1. Kehandalan

2. Kinerja

3. Daya Tahan

4. Servicebility

5. Estetika

\subsubsection{Promosi}

\subsubsection{Pengertian Promosi}

Kegiatan promosi merupakan salah satu bagian terpenting dalam perusahaan atau faktor penentu keberhasilan suatu program pemasaran dan juga sebagai arus informasi yang dibuat untuk mengarahkan seseorang atau organisasi kepada tindakan yang menciptakan pertukaran dalam pemasaran.Promosi juga merupakan kegiatan - kegiatan yang dilakukan oleh perusahaan (penjual) untuk mendorong konsumen untuk membeli produk atau jasa yang ditawarkan. Suatu produk tidak akan berguna selama produk tersebut tidak sampai ketangan konsumen yang membutuhkan dan tentunya konsumen tidak akan mengetahui akan keberadaan produk jika tanpa adanya kegiatan promosi. Oleh karena itu promosi dapat diartikan sebagai komunikasi awal antara perusahaan dan konsumen serta sebagai salah satu media untuk memperkenalkan produk kepada konsumen agar mengetahui akan keberadaan produk tersebut. 
Pengertian promosi menurut beberapa pendapat para ahli diantaranya promosi menurut Kotler dan Amstrong (2012), "promotion means activities that communicate the merits of the product and persuade target customers to buy it", artinya promosi merupakan kegiatan yang mengkomunikasikan manfaat dari sebuah produk dan membujuk target konsumen untuk membeli produk tersebut. Pada hakikatnya menurut Ratih Hurriyati (2010) promosi adalah suatu bentuk komunikasi pemasaran, yang merupakan aktivitas pemasaran yang berusaha menyebarkan informasi, mempengaruhi atau membujuk, dan mengingatkan pasar sasaran atas perusahaan dan produknya agar bersedia menerima, membeli, dan loyal pada produk yang ditawarkan perusahaan yang bersangkutan. Menurut Agus Hermawan (2013), promosi adalah salah satu komponen prioritas dari kegiatan pemasaran yang memberitahukan kepada konsumen bahwa perusahaan meluncurkan produk baru yang menggoda konsumen untuk melakukan kegiatan pembelian. Dapat disimpulkan bahwa promosi merupakan bagian penting dalam memasarkan suatu produk sehingga konsumen akan tertarik dan melakukan pembelian terhadap produk tersebut, sehingga suatu promosi perlu dirancang semenarik mungkin dan informasi yang disampaikan dapat dimengerti dengan mudah oleh masyarakat.

\subsubsection{Faktor - Faktor Yang Mempengaruhi Promotion}

Menurut Kotler dan Amstrong (2012:432), perpaduan spesifik iklan, promosi penjualan, hubungan masyarakat, penjualan personal, dan sarana pemasaran langsung yang digunakan perusahaan untuk mengkomunikasikan nilai pelanggan secara persuasive dan membangun hubungan pelanggan secara umum bentuk - bentuk memiliki fungsi yang sama, tetapi bentuk - bentuk tersebut dapat dibedakan berdasarkan tugas - tugas khususnya seperti penjualan perorangan, periklanan, promosi penjualan, hubungan masyarakat dan penjualan langsung. terdapat beberapa faktor yang mempengaruhi promosi yaitu :

\section{Periklanan (advertising)}

Periklanan yaitu semua bentuk presentasi dan promosi non personal yang dibayar oleh sponsor untuk mempresentasikan gagasan barang atau jasa. Iklan (advertising) juga merupakan penyajian informasi non personal tentang suatu produk, merk, perusahaan yang dilakukan dengan bayaran tertentu.Pada iklan biasanya ditampakkan organisasi yang mensponsorinya.Iklan ditujukan untuk mempengaruhi afeksi dan kognisi konsumen evaluasi, perasaan pengetahuan, makna kepercayaan, sikap dan citra yang berkaitan dengan produk dan merek.Dalam prakteknya, iklan telah dianggap sebagai manajemen citra (image management) menciptakan dan memelihara citra dan makna dalam benak konsumen. Walaupun Pertama - tama iklan akan mempengaruhi afeksi dan kognisi, tujuannya yang paling akhir adalah bagaimana mempengaruhi perilaku pembelian konsumen

2. Promosi Penjualan (sales promotion)

Promosi penjualan ialah insentif - insentif jangka pendek untuk mendorong pembelian atau penjualan suatu produk atau jasa. Bentuk promosi yang digunakan mencakup discounts, coupons, displays, demonstrations, contests, sweepstakes dan events.

3. Penjualan Perseorangan (personal selling)

Penjualan perseorangan adalah presentasi personal oleh tenaga penjualan dengan tujuan menghasilkan penjualan dan membangun hubungan dengan konsumen. Bentuk promosi yang digunakan mencakup presentations, trade shows dan incentive programs.

4. Hubungan Masyarakat (Public Relations) 
Hubungan masyarakat adalah membangun hubungan yang baik dengan berbagai publik perusahaan supaya memperoleh publisitas yang menguntungkan, membangun citra perusahaan yang bagus dan mengenai atau meluruskan rumor, cerita, serta event yang tidak menguntungkan. Bentuk promosi yang digunakan mencakup press releases, sponsorships, special event dan web pages.

5. Penjualan Langsung (Direct Marketing)

Penjualan langsung adalah hubungan langsung dengan sasaran konsumen dengan tujuan untuk memperoleh tanggapan segera dan membina hubungan yang abadi dengan konsumen. Bentuk promosi yang digunakan mencakup catalogs, telephone marketing, kiosks, internet, mobile marketing, dan lain sebagainya.

\subsubsection{Indikator Pengukuran Promotion}

Menurut Buchari Alma, (2011:181), promotion memiliki 5 (lima) indikator indikator sebagai berikut :

\section{Periklanan (advertising)}

John D. Burke menyatakan bahwa tahun 1890 advertising telah dirumuskan sebagai berita tentang barang dan jasa.Pada 1904 Kennedy, John E. (2009) memberikan defenisi advertising sebagai salesmanship in print. mendefenisikan advertising is a sales message directed at a mass audience, that seeks through, persuasion to sell goods, services, or ideas on behalf, of the paying sponsor. Yang dimana artinya prmosi menyampaikan pesan - pesan penjualan yang diarahkan kepada masyarakat melalui cara cara persuasif yang bertujuan menjual barang dan jasa maupun ide.

Menurut defenisi diatas periklanan adalah salah satu salah satu bentuk promosi yang paling banyak digunakan perusahaan dalam mempromosikan produknya, dan iklan adalah bentuk komunikasi tidak langsung yang didasarkan pada informasi tentang keunggulan atau keuntungan suatu produk, yang disusun sedemikian rupa sehingga menimbulkan rasa menyenangkan yang akan mengubah pikiran seseorang untuk melakukan pembelian.

\section{Penjualan perseorangan (personal selling)}

Komunikasi langsung (tatap muka) antara penjual dan calon pelanggan untuk memperkenalkan suatu produk kepada calon pelanggan dan membentuk pemahaman pelanggan terhadap produk sehingga mereka kemudian akan mencoba dan membelinya.

Bentuk personal selling yang kita kenal sebagai garis besarnya adalah sebagai berikut : di toko, rumah - rumah, penjual yang ditugaskan oleh pedagang besar untuk mendatangi pedagang eceran dan lain sebainya

\section{Hubungan Masyarakat (Public Relations and publicity)}

Kotler dan Gary menyebut ini public relations yang artinya menciptakan good relation dengan public, agar masyarakat memiliki image yang baik terhadap perusahaan, melalui public relation dapat membentuk pandangan baik dan mencegah berita - berita tak baik dari masyarakat.

Dari definisi di atas public relations merupakan upaya komunikasi menyeluruh dari suatu perusahaan untuk mempengaruhi persepsi, opini, keyakinan, dan sikap berbagai kelompok terhadap perusahaan tersebut.Dalam hal ini yang dimaksud dengan kelompok kelompok itu adalah mereka yang terlibat, mempunyai kepentingan, dan dapat mempengaruhi kemampuan perusahaan dalam mencapai tujuannya. 


\section{Promosi penjualan (sales promotion)}

Bentuk persuasi langsung melalui penggunaan berbagai insentif yang dapat diatur untuk merangsang pembelian produk dengan segera dan meningkatkan jumlah barang yang dibeli pelanggan.

\section{Penjualan Langsung (direct marketing)}

Yaitu hubungan langsung dengan sasaran konsumen dengan tujuan untuk memperoleh tanggapan segera dan membina hubungan yang abadi dengan konsumen. Bentuk promosi yang digunakan mencakup catalogs, telephone marketing, kiosks, internet, mobile marketing, dan lainnya.

\section{Kerangka Konseptual}

Kerangka konseptual yang digunakan dalam penelitian ini dapat dilihat pada gambar 2.4 dibawah ini

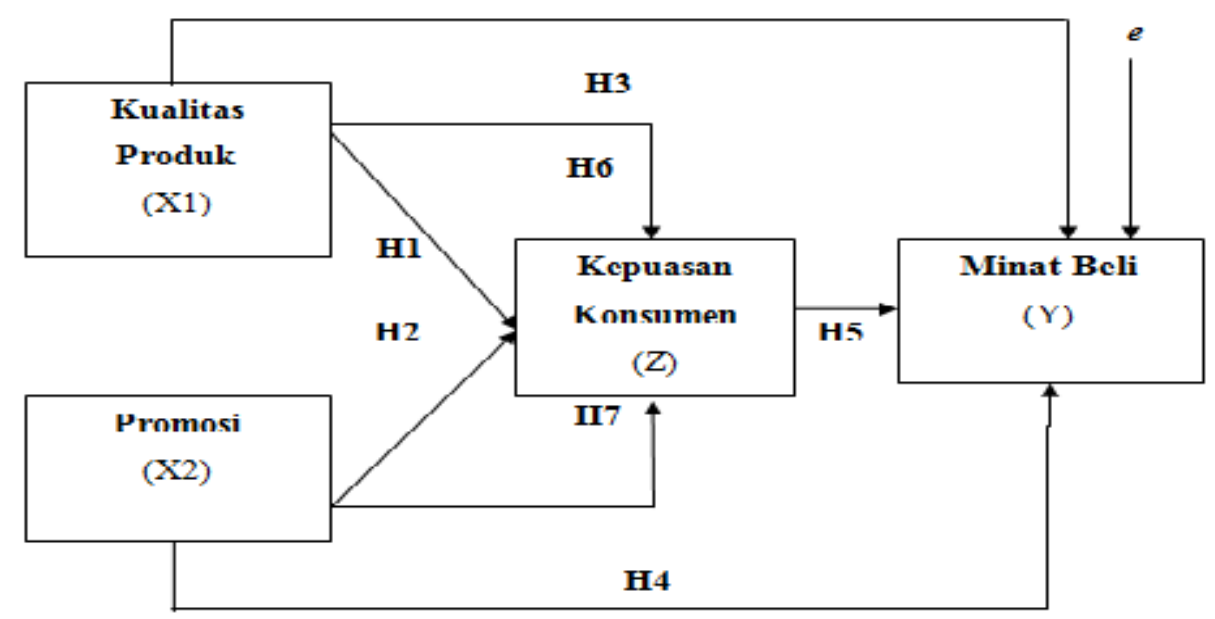

\section{Hipotesis Penelitian}

Berdasarkan dengan permasalahan yang telah dikemukakandan kerangka konseptual yang telah diuraikan diatas maka dapat dirumuskan hipotesis penelitian sebagai berikut :

H1 : Diduga Kualitas Produk berpengaruh positif dan signifikan terhadap Kepuasan Konsumen pada PT. Menara Agung.

H2 : Diduga Promosi terhadap berpengaruh positif dan signifikanKepuasan Konsumen pada PT. Menara Agung.

H3 : Diduga Kualitas Produk berpengaruh signifikan terhadap Minat Beli pada PT. Menara Agung.

H4 : Diduga Promosi berpengaruh positisf dan signifikan terhadap Minat Beli pada PT. Menara Agung.

H5 : Diduga Kepuasan Konsumen berpengaruh positif dan signifikan terhadap Minat Beli pada PT. Menara Agung.

H6 : Diduga Kualitas Produk berpengaruh positif dan signifikan terhadap Minat Beli dengan Kepuasan Konsumen sebagai variabel intervening pada PT. Menara Agung.

H7 : Diduga Promosi berpengaruh positif dan signifikan terhadap Minat Beli dengan Kepuasan Konsumen sebagai variabel intervening pada PT. Menara Agung. 


\section{METODE PENELITIAN \\ Objek Penelitian}

Objek dalam penelitian ini adalah PT. Menara Agung yang beramat di Jl. Veteran No 30 Padang, yang merupakan sebuah perusahaan yang bergerak dibidang penjualan kendaraan roda dua atau main dealer resmi Honda Di kota Padang.

\section{Populasi}

Menurut Sugiyono (2016:215) Populasi adalah wilayah generalisasi yang terdiri atas obyek dan subyek yang mempunyai kualitas dan kharakteristik tertentu yang ditetapkan oleh peneliti untuk dipelajari kemudian ditarik kesimpulannya. Populasi bukan hanya orang, tetapi juga obyek dan benda-benda alam lainnya. Populasi juga bukan sekedar jumlah yang ada pada obyek atau subyek yang dipelajari, tetapi meliputi kharakteristik atau sifat yang dimiliki oleh subyek atau obyek itu.

Adapun populasi dalam penelitian ini adalah konsumen yang melakukan pembelian di PT. Menara Agung. Populasi penelitian ini terdiri dari beberapa kelas yang berbeda, sehingga perlu dilakukan sampling, yaitu dengan penentuan jumlah sampel yang dikehendaki, artinya kuota ditentukan dan tiap kelas yang ada, tetapi berdasarkan sampel yang akan diambil.

\section{Sampel}

Menurut Sugiyono (2016:81) menyatakan bahwa Sampel adalah bagian dari jumlah dan karakteristik yang dimiliki oleh populasi tersebut. Bila populasi besar, dan peneliti tidak mungkin mempelajari semua yang ada pada populasi, maka peneliti dapat menggunakan sampel yang dari populasi itu. Sampel yang digunakan dalam penelitian ini adalah konsumen dari PT. Menara Agung.

Metode yang digunakan dalam pengambilan sampel pada penelitian ini adalah metode Non Probability Sampling dikarenakan peneliti tidak mendapatkan data secara rinci identitas responden yang diperlukan dalam pembuatan kerangka sampling.

Metode Non Probability Sampling dengan tipe Purpose Sampling yaitu pengambilan sampel yang membatasi pada ciri-ciri khusus seseorang yang memberikan informasi yang dibutuhkan. Adapun ciri-ciri nya adalah :

1. Jenis kelamin pria dan wanita yang melakukan pembelian produk di PT. Menara Agung.

2. Telah mencapai umur 18 tahun - 60 tahun ke atas, dengan alasan mereka sudah dapat menentukan keputusan sendiri.

3. Berbagai latar belakang perkerjaan dari semua konsumen di PT. Menara Agung.

4. Adanya konsumen individu dan kelompok atau organisasi.

Ukuran sampel yang harus dipenuhi dalam pemodelan adalah minimum berjumlah 100 dan selanjutnya menggunakan perbandingan 5 observasi untuk setiap estimated paramater (indikator) menurut Visi Hardiani (2016). Jumlah sampel yang tidak diketahui jumlah populasi pastinya, minimal berjumlah lima kali variabel yang dianalisa atau indikator. Maka jumlah sampel pada penelitian ini adalah :

$$
\begin{aligned}
\text { Jumlah sampel } & =\text { Jumlah indikator } \times 5 \\
& =20 \times 5 \\
& =100
\end{aligned}
$$

Berdasarkan perhitungan diatas, didapat untuk sampel minimum sebanyak 100 sampel responden. 


\section{Teknik Pengumpulan Data}

Untuk mendapatkan data yang diperlukan dalam penelitian ini dilakukan dengan cara kuesioner. Kuesioner merupakan teknik pengumpulan data yang dilakukan dengan cara memberi seperangkat pertanyaan atau pertanyaan tertulis kepada responden untuk dijawab. Kuesioner cocok digunakan apabila jumlah responden cukup besar dan tersebar di wilayah yang luas (Sugiyono, 2012:162). Pengumpulan data dengan cara memberikan atau menyebarkan daftar pertanyaan tentang kepuasan kerja, kompensasi finansial, dan penilaian kinerja kepada responden dengan harapan responden memberikan respon atas daftar pernyataan tersebut.

\section{Metode Analisis Data}

Metode analisis data adalah suatu metode yang digunakan untuk memperoleh suatu kesimpulan. Pengolahan data ini digunakan untuk menguji hipotesis yang telah dirumuskan.

\section{Analisis Regresi Berganda}

Penelitian ini menggunakan model analisis regresi linear berganda untuk membuktikan hipotesis penelitian. Analisis ini akan menggunakan input berdasarkan data yang diperoleh dari kuesioner. Perhitungan statistik dalam analisis regresi linear berganda yang digunakan dalam penelitian ini adalah dengan menggunakan bantuan program dari SPSS (statistical package for social science). Menurut Sugiyono (2014:267), secara umum regresi linear berganda dapat dirumuskan sebagai berikut :

$$
Y=a+b_{1} x_{1}+b_{2} x_{2}+b_{2} z+e
$$

$$
\begin{aligned}
& \text { Keterangan : } \\
& \mathrm{Y}=\text { Minat Beli } \\
& \text { a = Standar koefisien (konstanta) } \\
& \mathrm{X} 1=\text { Kualitas Produk } \\
& \mathrm{X} 2=\text { Promosi } \\
& b_{1} b_{2}=\text { koefisien regresi } \\
& \mathrm{Z}=\text { Kepuasan Konsumen } \\
& \text { e } \quad=\text { Kesalahan Pengganggu (standar error) }
\end{aligned}
$$

\section{Analisis Jalur (Path Analysis)}

Untuk menguji pengaruh variabel intervening digunakan metode analisis jalur yang merupakan perluasan dari analisis regresi linear berganda atau analisis jalur adalah penggunaan analisis regresi untuk menaksir hubungan kausalitas antar variabel (model casual) yang telah ditetapkan sebelumnya berdasarkan teori dan menentukan pola hubungan antara tiga atau lebih variabel dan tidak dapat digunakan untuk mengkonfirmasi atau menolak hipotesis, Ghozali, (2013:249).

Dalam analisis jalur sebelum penelitian melakukan analisis suatu penelitian, terlebih dahulu peneliti membuat diagram jalur yang digunakan untuk mempresentasikan permasalahan dalam bentuk gambar dan menentukan persamaan struktural yang menyatakan hubungan antara variabel pada diagram jalur tersebut. (Juliansyah Noor, 2014) menyatakan bahwa, diagram jalur dapat digunakan untuk menghitung pengaruh langsung dan tidak langsung dari variabel independen terhadap suatu variabel dependen. Pengaruh-pengaruh itu tercermin dalam apa yang disebut dengan koefisien jalur, dimana secara matematik analisis jalur mengikuti mode struktural. Dengan gambar sebagai berikut 
Gambar 3.1

Diagram Jalur

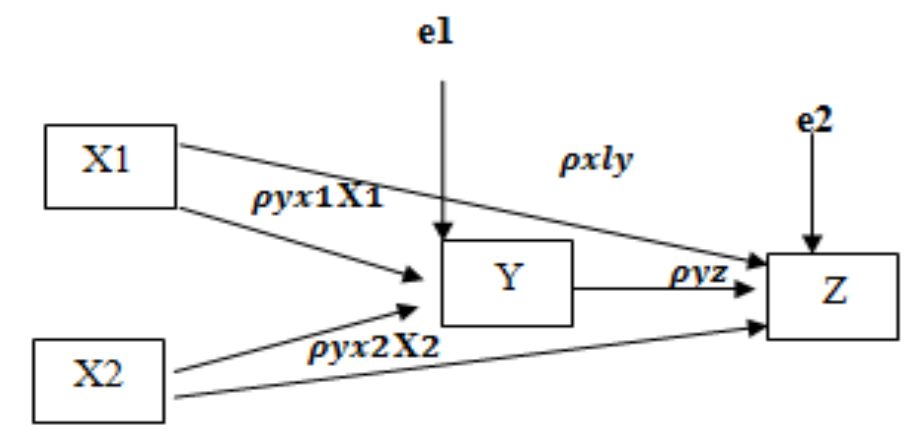

\section{HASIL PENELITIAN}

Berikut ini tabel Persamaan I : Kualitas Produk (X1) dan Minat Beli (X2) Terhadap Kepuasan Konsumen (Z)

Tabel : Persamaan I

Kualitas Produk (X1) dan Minat Beli (X2)

Terhadap Kepuasan Konsumen (Z)

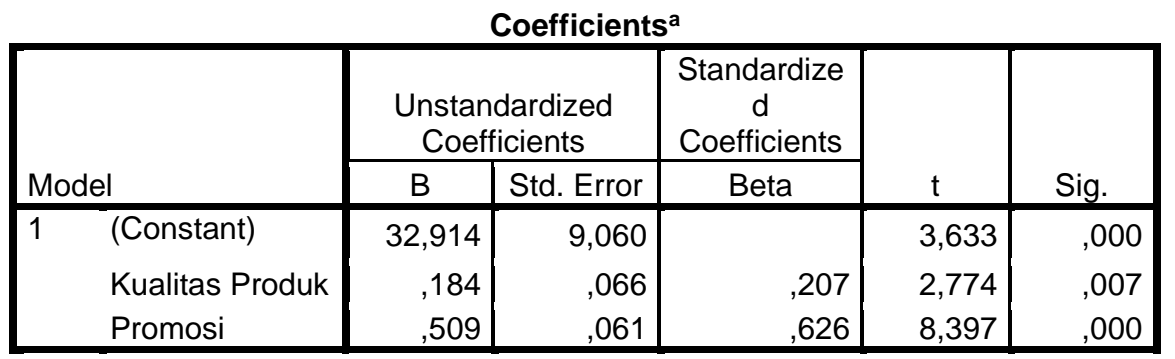

a. Dependent Variable: Kepuasan Konsumen

Sumber : SPSS 22.0 Dan Data Primer (diolah)

Dan Tabel Persamaan II : Kualitas Produk (X1) dan Promosi (X2) Terhadap Minat Beli (Y) Melalui Kepuasan Pelanggan (Z) Sebagai Variabel Intervening

Tabel Persamaan II

Analisis Regresi Linier Berganda Kualitas Produk (X1) dan Promosi (X2) Terhadap

Minat Beli (Y) Melalui Kepuasan Pelanggan (Z) Sebagai Variabel Intervening Persamaan II

Coefficients $^{a}$

\begin{tabular}{|c|c|c|c|c|c|}
\hline \multirow[b]{2}{*}{ Model } & \multicolumn{2}{|c|}{$\begin{array}{l}\text { Unstandardized } \\
\text { Coefficients }\end{array}$} & $\begin{array}{c}\text { Standardized } \\
\text { Coefficients }\end{array}$ & \multirow[b]{2}{*}{$\mathrm{T}$} & \multirow[b]{2}{*}{ Sig. } \\
\hline & $\mathrm{B}$ & Std. Error & Beta & & \\
\hline $1 \quad$ (Constant) & 23,077 & 10,641 & & 2,169 & ,033 \\
\hline Kualitas Produk &,- 241 & ,076 &,- 214 & $-3,170$ & ,002 \\
\hline Promosi & ,465 & ,088 & ,452 & 5,292 & ,000 \\
\hline Kepuasan Konsumen & ,535 & , 112 & , 423 & 4,780 &, 000 \\
\hline
\end{tabular}

a. Dependent Variable: Minat Beli 


\section{Sumber : SPSS 22.0 Dan Data Primer (diolah)}

Berdasarkan tabel 4.20 diatas, dapat diinterpretasikan sebagai berikut :

1. Pengaruh Kualitas Produk (X1) terhadap Kepuasan Konsumen (Z)

Berdasarkan tabel 4.20 menunjukkan bahwa variabel Kualitas Produk (X1) dengan nilai signifikan 0,007<0,05 dan nilai t-hitung lebih besar dari $t$-tabel 2,774>1,984, maka dapat disimpulkan Ho ditolak dan Ha diterima, berarti variabel Kualitas Produk berpengaruh signifikan terhadap variabel Kepuasan Konsumen.

2. Pengaruh Promosi (X2) terhadap Kepuasan Konsumen (Z)

Berdasarkan tabel 4.20 menunjukkan bahwa variabel Promosi (X2) dengan nilai signifikan $0,000<0,05$ dan nilai $\mathrm{t}$-hitung lebih besar dari $\mathrm{t}$-tabel $8,397>1,984$, maka dapat disimpulkan Ho ditolak dan Ha diterima, berarti variabel Promosi berpengaruh signifikan terhadap variabel Kepuasan Konsumen.

\section{Pengaruh Kualitas Produk (X1) terhadap Minat Beli (Y)}

Berdasarkan tabel 4.21 menunjukkan bahwa variabel Kualitas Produk (X1) dengan nilai signifikan $0,000<0,05$ dan nilai t-hitung lebih kecil dari $\mathrm{t}$-tabel 3,918>1,984, maka dapat disimpulkan Ho ditolak dan Ha diterima, berarti variabel Kualitas Produk berpengaruh signifikan terhadap variabel Minat Beli.

4. Pengaruh Promosi (X2) terhadap Minat Beli (Y)

Berdasarkan tabel 4.21 menunjukkan bahwa variabel Kualitas Produk (X2) dengan nilai signifikan 0,000<0,05 dan nilai t-hitung lebih besar dari $t$-tabel 5,292>1,984, maka dapat disimpulkan Ho ditolak dan Ha diterima, berarti variabel Promosi berpengaruh signifikan terhadap variabel Minat Beli.

5. Pengaruh Kepuasan Konsumen (Z) terhadap Minat Beli (Y)

Berdasarkan tabel 4.21 menunjukkan bahwa variabel Kepuasan Konsumen (Z) dengan nilai signifikan $0,019<0,05$ dan nilai t-hitung lebih besarl dari t-tabel $4,780<1,988$, maka dapat disimpulkan Ho ditolak dan Ha diterima, berarti variabel Kepuasan Konsumen berpengaruh signifikan terhadap Variabel Minat Beli.

\section{Path Analysis / Analisis Jalur}

Berdasarkan persamaan yang di dapat dari analisis regresi berganda pada model 1 dan II maka dapat dirumuskan diagram jalur model 3 sebagai berikut:

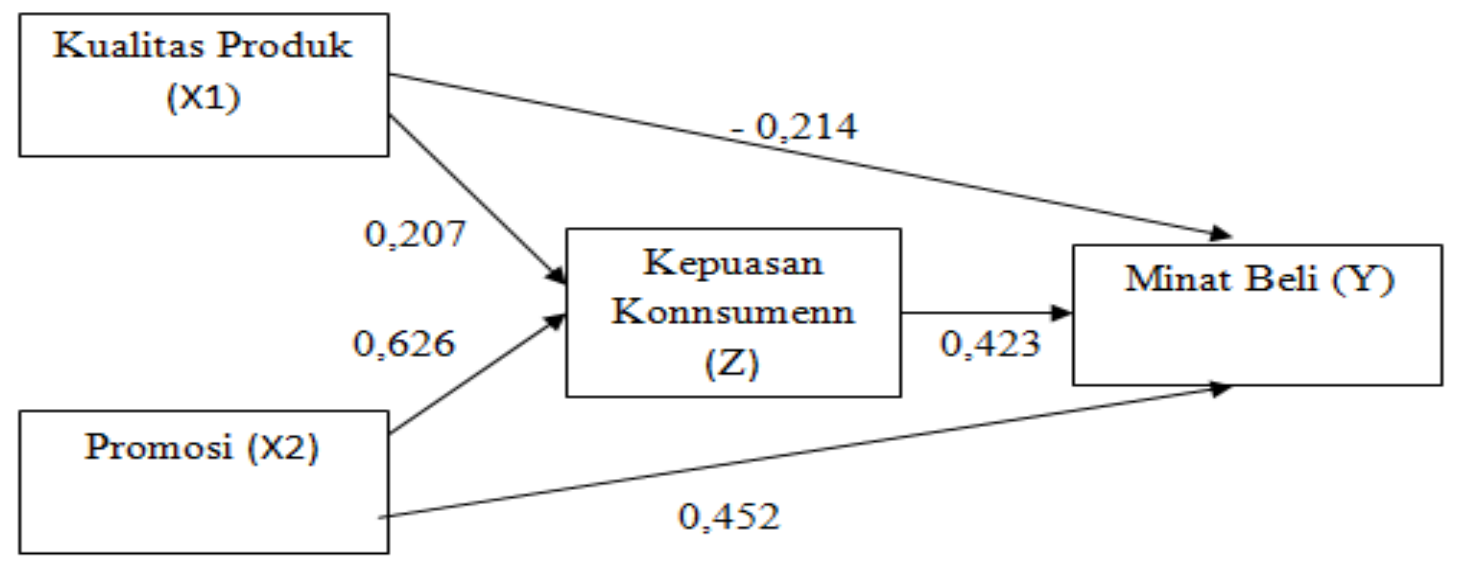

Gambar 4.6 Path Anlysis

Berdasarkan diagram jalur yang telah dirumuskan maka dapat disumpulkan pengaruh lansung dan tidak lansung sebagai berikut : 


\section{Pengaruh Kualitas Produk (X1) terhadap Minat Beli (Y) melalui Kepuasan Konsumen $(Z)$ sebagai variabel intervening.}

a) Hubungan langsung Kualitas Produk (X1) terhadap Minat Beli (Y) sebesar = 0,214 .

b) Hubungan tidak langsung Kualitas Produk (X1) terhadap Minat Beli (Y) melalui Kepuasan Konsumen $(Z)$ sebagai variabel intervening sebesar $=0,207$ X 0,423 = 0,088. Dengan total pengaruh langsung dan tidak langsung sebesar $=-0,214+$ $0,088=-0,126$.

Maka dapat disimpulkan bahwa hubungan tidak langsung lebih besar dibandingkan dengan hubungan langsung, berarti Kepuasan Konsumen (Z) memediasi hubungan antara Kualitas Produk (X1) terhadap Minat Beli (Y)

\section{Pengaruh Promosi (X2) terhadap Minat Beli (Y) melalui Kepuasan Konsumen (Z)} sebagai variabel intervening.

a) Hubungan langsung Promosi (X2) terhadap Minat Beli (Y) sebesar =0,452.

b) Hubungan tidak langsung Promosi (X2) terhadap Minat Beli (Y) melalui Kepuasan Konsumen $(Z)$ sebagai variabel intervening sebesar $=0,626 \mathrm{X} \quad 0,423=0,264$. Dengan total pengaruh langsung dan tidak langsung sebesar $=0,452+0,264=$ 0,716 .

Maka dapat disimpulkan bahwa hubungan tidak langsung lebih kecil dibandingkan dengan hubungan langsung, berarti Kepuasan Konsumen (Z) tidak memediasi hubungan antara Promosi (X2) terhadap Minat Beli (Y)

Berdasarkan uraian diatas maka dapat disimpulkan bahwa ketujuh hipotesis penelitian yang sebelumnya dapat disimpulkan pada tabel 4.26 sebagai berikut :

Tabel 4.26

Hasil Pengujian Hipotesis Penelitian

\begin{tabular}{|c|c|c|c|}
\hline Hipotesis & Pernyataan & Signifikan & Keputusan \\
\hline $\mathrm{H} 1$ & $\begin{array}{l}\text { Diduga Kualitas Produk berpengaruh } \\
\text { signifikan terhadap Kepuasan } \\
\text { Konsumen }\end{array}$ & $0,007<0,05$ & Diterima \\
\hline $\mathrm{H} 2$ & $\begin{array}{l}\text { Diduga Promosi berpengaruh } \\
\text { signifikan terhadap Kepuasan } \\
\text { Konsumen }\end{array}$ & $\mathbf{0 , 0 0 0}<\mathbf{0 , 0 5}$ & Diterima \\
\hline $\mathrm{H} 3$ & $\begin{array}{l}\text { Diduga Kualitas Produk berpengaruh } \\
\text { signifikan terhadap Minat Beli }\end{array}$ & $0,002<0,05$ & Diterima \\
\hline $\mathrm{H} 4$ & $\begin{array}{l}\text { Diduga Promosi berpengaruh } \\
\text { signifikan terhadap Minat Beli }\end{array}$ & $0,000<0,05$ & Diterima \\
\hline $\mathrm{H} 5$ & $\begin{array}{l}\text { Diduga Kepuasan Konsumen } \\
\text { berpengaruh signifikan terhadap Minat } \\
\text { Beli }\end{array}$ & $0,000<0,05$ & Diterima \\
\hline
\end{tabular}




\begin{tabular}{|c|l|c|c|}
\hline H6 & $\begin{array}{l}\text { Diduga Kualitas Produk berpengaruh } \\
\text { signifikan terhadap Minat Beli dengan } \\
\text { Kepuasan Konsumen sebagai variabel } \\
\text { intervening }\end{array}$ & $\mathbf{0 , 0 8 8}>\mathbf{- 0 , 2 1 4}$ & Memediasi \\
\hline H7 & $\begin{array}{l}\text { Diduga Promosi berpengaruh } \\
\text { signifikan terhadap Minat Beli dengan } \\
\text { Kepuasan Konsumen sebagai variabel } \\
\text { intervening }\end{array}$ & $\mathbf{0 , 2 6 4}<\mathbf{0 , 4 5 2}$ & $\begin{array}{c}\text { Tidak } \\
\text { Mediasi }\end{array}$ \\
\hline
\end{tabular}

Sumber :SPSS 16.0 dan data primer yang diolah

\section{KESIMPULAN}

Berdasarkan penelitian yang dilakukan peneliti lakukan melalui analisis statistik dari kuesioner yang di sebarkan maka dapat ditarik kesimpulan sebagai berikut :

1. Terdapat pengaruh Positif dan signifikan Kualitas Produk (X1) terhadap Kepuasan Konsumen (Z) pada PT. Menara Agung. Semakin baik Kualitas Produk yang diberikan maka semakin tinggi tingkat Kepuasan Konsumen

2. Terdapat pengaruh positif dan signifikan Promosi (X2) terhadap Kepuasan Konsumen (Z) pada PT. Menara Agung. Semakin bagus Promosi yang diberikan maka akan meningkatkan Kepuasan Konsumen.

3. Terdapat pengaruh positif dan signifikan Kualits Produk (X1) terhadap Minat Beli (Y) Pada PT. Menara Agung. Semakin terjamin Kualitas Produk maka semakin meningkat Loyalitas Minat Beli.

4. Terdapat pengaruh positif dan signifikan Promosi (X2) terhadap Minat Beli (Y) Pada PT. Menara Agung. Semakin baik Promosi maka semakin meningkat Minat Beli.

5. Terdapat pengaruh positif dan signifikan Kepuasan Konsumen (Z) terhadap Minat Beli (Y) Pada PT. Menara Agung. Semakin tinggi Kepuasan Konsumen maka semakin meningkatkan Minat Beli.

6. Berdasarkan hasil path analysis persamaan satu sebesar 0,088 >-0,214, Artinya hubungan tidak langsung lebih besar nilainya dari hubungan langsung, berarti Kepuasan Konsumen (Z) memediasi hubungan antara Kualitas Produk (X1) terhadap Minat Beli (Y).

7. Berdasarkan hasil path analysis persamaan dua sebesar 0,264 $<0,452$, Artinya hubungan tidak langsung lebih kecil nilainya dari hubungan langsung, berarti Kepuasan Konsumen (Z) tidak memediasi hubungan antara Promosi (X2) terhadap Minat Beli (Y).

\subsection{Saran}

Berdasarkan kesimpulan yang telah dibuat, maka penulis mengemukakan beberapa saran sebagai berikut :

a) Agar dapat meningkatkan Kualitas Produk kepada pelanggan dengan cara memberikan pelayanan yang baik karena terbukti dapat meningkatkan Minat Beli.

b) Agar dapat meningkatkan Promosi dengan cara memberikan diskon, dan juga melakukan direct Marketing, Advertising beserta Public relation agar dapat meningkatkan Kepuasan Konsumen.

c) Agar dapat meningkatkan Kepuasan Konsumen dengan cara memberikan perhatian yang khusus kepada pelanggan, memberikan keuntungan kepada pelanggan setia dan menawarkan program yang baik agar bisa meningkatkan Minat Beli. 


\section{DAFTAR PUSTAKA}

Tjiptono, Fandy., Chandra, Gregorius, \& Adriana, Dadi. (2008). Pemasaran Strategik. Yogyakarta : Penerbit Andi

Sugiyono. 2010. Metode Penelitian Binis. Bandung: AlfaBeta dan PT. Gramedia Pustaka Utama.

Ghozali, Imam., 2006, Aplikasi Analisis Multivariate dengan Program SPSS, Edisi 4, Semarang: Badan Penerbit Universitas Diponegoro.

Rangkuti, Freddy. 2009. Riset Pemasaran, Jakarta: PT. Gramedia Pustaka Utama

Kotler, P., \& Keller, K.L. 2009.Manajemen Pemasaran, edisi ketiga belas. Jakarta: Erlangga.

Kotler, Philip and Gary, Amstrong, (2008). Principles of Marketing. Twelfth Edition. Pearson Education. New Jersey. 